\title{
Movement of walleye in an impounded reach of the Au Sable River, Michigan, USA
}

\author{
Michele M. DePhilip ${ }^{\mathrm{a}}$, James S. Diana ${ }^{\mathrm{b}}$ \& David Smith \\ ${ }^{a}$ The Nature Conservancy, Great Lakes Program, 8 S. Michigan Avenue, Suite 2301, Chicago, IL 60603, \\ U.S.A. (e-mail: mdephilip@tnc.org) \\ ${ }^{\mathrm{b}}$ School of Natural Resources and Environment, University of Michigan, Dana Building, Ann Arbor, MI \\ 48109, U.S.A. \\ ${ }^{\mathrm{c}}$ Huron Pines Resource Conservation \& Development Area Council, Inc., 401 Norway Street, Grayling, MI \\ 49738, U.S.A.
}

Received 12 August $2003 \quad$ Accepted 30 July 2004

Key words: telemetry, habitat, dams, migration, diel activity

\section{Synopsis}

We estimated long-range spawning and foraging movements of walleye and observed their use of river and reservoir habitats between two large hydroelectric dams on the Au Sable River, Michigan. We used radiotelemetry to monitor seasonal and daily movements of 11 large walleye. Walleye ranged throughout the entire reach between the two dams. Eight of the 11 fish used both river and reservoir locations. Walleye migrated upriver in April or May and presumably spawned near the dam tailwaters. After spawning, walleye remained in the river for up to 6 months, usually establishing local ranges. During this time, they occupied low-velocity refuges within the first $25 \mathrm{~km}$ of the upstream dam. They seldom occupied the downstream area, which has higher variation around the mean temperature. Food availability and water temperature may have affected the length of time that walleye remained in the river after spawning. All walleye overwintered in the reservoir. We designed this study to evaluate if walleye have a potential negative impact on brown trout, Salmo trutta. In summer, walleye were often present near sites where fingerling trout were stocked. We found the highest potential for interaction between the two species occurs within the first $25 \mathrm{~km}$ of the upstream dam during summer. The movement patterns of and habitats used by large walleye validate concerns that walleye could compete with adult brown trout for food and resting sites and prey on juvenile brown trout.

\section{Introduction}

Walleye Stizostedion vitruem make long-range movements associated with spawning and foraging in the Great Lakes (Furguson \& Dersken 1971, Haas et al. 1988), inland lakes (Holt et al. 1977, Diana et al. 1990), and rivers (Rawson 1957 , Paragamian 1989). Distribution of feeding, spawning, and overwintering habitats affects long-range movements of stream fishes (Schlosser 1991). In north-temperate streams, adult fish experience seasonally favorable periods with conditions for rapid growth and unfavorable periods with reduced growth. As a result of this temporal variation, adult fish often migrate between summer and winter habitats (Schlosser 1991). Sexually mature fish may also migrate to suitable spawning areas.

In impounded river systems, walleye often move to dam tailwaters to spawn (Crowe 1962, Ager 1976, Paragamian 1989). The presence of dams facilitated establishment of naturally reproducing walleye populations in impounded reaches of the 


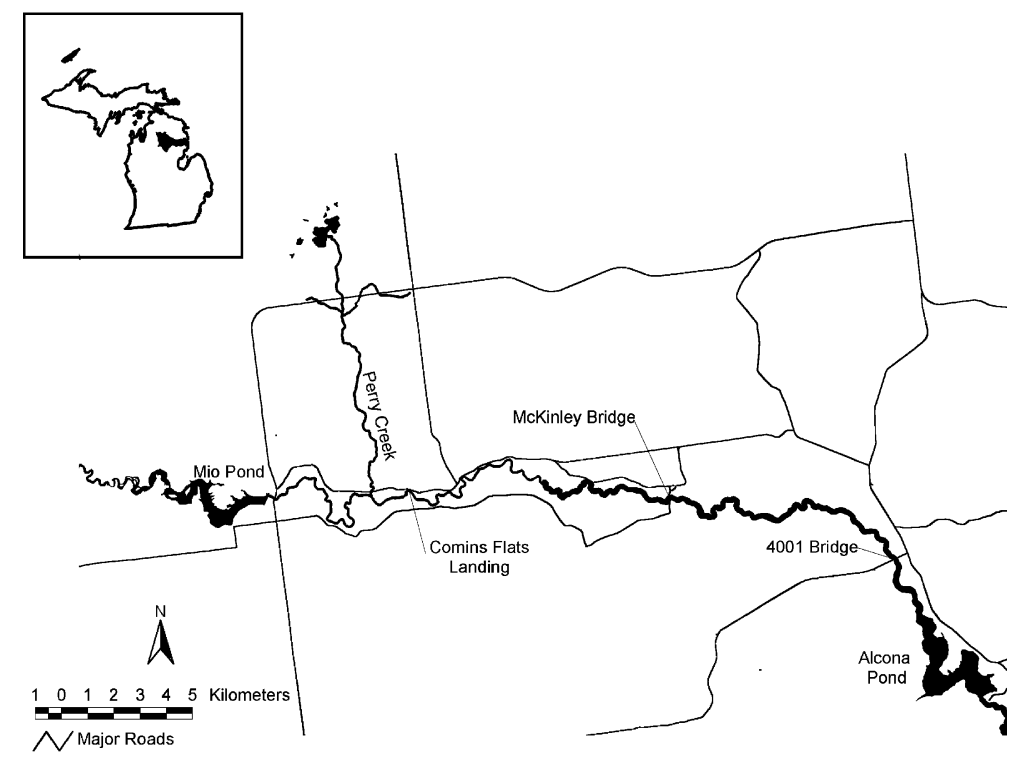

Figure 1. Map of the study site within the Au Sable River system. The study site was between Mio and Alcona dams and consisted of two study areas: upstream area, from Mio Dam to McKinley Bridge; downstream area, from McKinley Bridge to the backwaters of Alcona Pond.

$\mathrm{Au}$ Sable River. Walleye are known to inhabit Alcona Pond. Walleye also congregate below Mio Dam in April, which suggests that they range throughout the entire reach between Mio and Alcona dams. Separation of walleye spawning and overwintering habitats could result in longrange movements by walleye in the Au Sable River.

In their native range, rivers and lakes with walleye and salmonids are relatively rare and where they do co-occur, the species have little spatial overlap due to different habitat requirements (McMahon \& Bennett 1996). The Au Sable River between Mio and Alcona dams provided a unique environment to study range and behavior of two large piscivorous fish species, walleye and brown trout Salmo trutta. Forced coexistence of brown trout and walleye has generated concern that these two species compete for food and that adult walleye prey on juvenile brown trout. The brown trout fishery is made up almost entirely of stocked fish. Stocked brown trout may be especially vulnerable to predation due to lack of cover.

We used radiotelemetry to study seasonal and diel movements of walleye. Long battery life permitted continuous observation of individual fish throughout the study (Diana et al. 1990). The study objectives were to: (1) estimate long-range movements of walleye associated with spawning or foraging; (2) relate these movements to river and reservoir habitats available within the impounded reach between Mio and Alcona dams; and (3) explore the interaction between walleye and brown trout, popular sportfish in the Mainstream $\mathrm{Au}$ Sable River.

\section{Study site}

The Mainstream Au Sable River originates north of Grayling, Michigan and flows east to Lake Huron. Mio Dam, $117 \mathrm{~km}$ from Lake Huron, was the upstream boundary of the study reach (Figure 1). From Mio Dam, the river flows approximately $37.8 \mathrm{~km}$ to the backwaters of Alcona Pond. Each spring, this reach is stocked with brown trout and rainbow trout, Oncorynchus mykiss. ${ }^{1}$ Alcona Pond covers approximately 435 ha and is surrounded by Alcona County Park. Stumps and aquatic

\footnotetext{
${ }^{1}$ Michigan Department of Natural Resources. 2002. Fish Stocking Database [Online]. Available: www.dnr.state.mi.us/ fishstock [2002, May 12].
} 
macrophyte growth provide structure throughout the reservoir. A maximum depth of $14 \mathrm{~m}$ occurs within the old river channel; however, most of the reservoir is less than $3 \mathrm{~m}$ deep. Walleye were stocked in Alcona Pond until 1990.

McKinley Bridge divided the study site into two study areas. The upstream area, from Mio Dam to McKinley Bridge, had higher gradient, more rifflepool sequences, and more large woody debris than the downstream area. The upstream area had an average daily discharge of $30.5 \mathrm{~m}^{3} \mathrm{~s}^{-1}$, an average width of $46 \mathrm{~m}$, and an average gradient of $0.14 \%$. Gravel and pebble were the dominant substrate types. The downstream study area, from McKinley Bridge to the backwaters of Alcona Pond, had lower gradient, more run habitat, and less large woody debris than the upstream area. This area had an average daily discharge of $33.5 \mathrm{~m}^{3} \mathrm{~s}^{-1}$, an average width of $51 \mathrm{~m}$, and an average gradient of $0.05 \%$. Pebble and cobble were the dominant substrate types.

\section{Methods}

\section{Transmitter implants}

In May 1996, we used DC electrofishing gear to capture five walleye between Mio Dam and Comins Flats Landing. We anesthetized fish with $75 \mathrm{mg}^{-1}$ of tricaine methane sulfonate (MS-222) in river water. We inserted transmitters into the abdominal cavity through a $2.5-\mathrm{cm}$ mid-ventral incision between the pelvic and pectoral girdles then closed the incision with nonabsorbable nylon sutures. Following surgery, we injected $2 \mathrm{ml}$ of oxytetracycline $(50 \mathrm{mg} / \mathrm{ml})$ through the incision to prevent infection. The procedure took less than 10 min to complete and all fish were released at Comins Flats Landing.

In April 1997, we used DC electrofishing gear to capture seven walleye from three locations. On 3 April, we captured two female walleye from Alcona Pond, implanted them with transmitters using surgical techniques described above, and released them. On 4 April, we captured one male and two females just below Mio Dam, implanted, and released them $0.5 \mathrm{~km}$ below Mio Dam. We captured the remaining two male walleye between Perry
Creek and Comins Flats Landing, implanted, and released them at Comins Flats Landing.

We used two models of radio transmitters in this study (Advanced Telemetry Services, Isanti, MN). Transmitters used in 1996 were powered by a lithium battery equipped with an internal coil antenna, weighed 17-19 g, and had an expected life of 200-400 days. Transmitters used in 1997 were of similar weight and battery life expectancy but had a $25-30 \mathrm{~cm}$ trailing antenna that passed through the body wall. We used a shielded needle technique to allow the antenna to protrude (Ross \& Kleiner 1982). All transmitters had identifying labels, including a telephone number to call if someone caught the fish or found the transmitter. All transmitters were encapsulated in a biologically inert resin to prevent tissue reaction. Each transmitter emitted a unique frequency between 48 and $48.5 \mathrm{MHz}$.

\section{Fish locations}

Immediately following surgery, we monitored radio-tagged fish using a programmable scanning receiver (Model R2100) and a 60-cm directional loop antenna (both from Advanced Telemetry Services). We tracked fish from a canoe or from shore during daylight hours. When Alcona Pond was frozen, we walked on the surface and tracked fish through the ice. We could detect a signal from approximately $250 \mathrm{~m}$. Once we detected a signal, we located fish by triangulation and marked its position on a set of aerial photographs (United States Department of Agriculture, Soil Conservation Service 1991). In summer (May-August), we located fish three to four times each week. In winter (September-April), we located fish once or twice each month.

We did not use data collected during the first 2 weeks after surgery since fish may exhibit erratic behavior during this time (Mesing \& Wicker 1986). In summer and winter, we determined the difference between extreme upstream and downstream locations to be the seasonal range of movement for an individual fish. We also calculated total range of movement for fish tracked in more than one season. We defined local range as a reach within the total range where we repeatedly located an individual fish, or as a reach to which a fish returned after an absence. In the reservoir, if we located an individual 
walleye within the same bay more than five times, we defined this bay as its local range. We tracked five walleye through October 1997, but we only used data collected through August 1997 to compute seasonal range size.

\section{Daily activity}

We measured diel activity during summer 1996 and 1997. Although walleye occupied river and reservoir local ranges, we only measured diel activity in the river. We located an individual fish four times in $24 \mathrm{~h}$ : at sunrise, at mid-day, at sunset, and during night. At each of the four periods, we spent $1 \mathrm{~h}$ monitoring activity of one fish. We divided the hour into 5-min intervals and listened for changes in signal strength during each interval. If we detected a change in signal strength during an interval, we considered the fish to be active. We calculated the percent of active intervals at each of the four periods to find peaks in activity. If a fish moved measurable distances during the observation period, we also estimated total linear distance moved.

\section{Habitat use}

We collected quantitative habitat measurements within riverine local ranges used by six walleye during summer. We used three transects to characterize each reach. We established the focal transect through the point where the fish was most frequently observed. We established a second transect $50 \mathrm{~m}$ upstream of the focal transect and a third transect $50 \mathrm{~m}$ downstream of the focal transect. In two cases, we used four transects $50 \mathrm{~m}$ apart to characterize large local ranges. We measured water depth, surface velocity, mean column velocity, substrate, and cover type at $5 \mathrm{~m}$ intervals along each transect. We measured surface and mean water velocity (at 0.6 of the water column depth) using a Swoffer Open Stream velocity meter. We visually estimated predominant substrate type at each sampling point along the transect and categorized the substrate as silt $(<0.125 \mathrm{~mm})$, sand $(0.125-$ $2 \mathrm{~mm})$, gravel $(2-16 \mathrm{~mm})$, pebble $(17-64 \mathrm{~mm})$, cobble $(65-256 \mathrm{~mm})$ or boulder $(>256 \mathrm{~mm})$. We classified predominant cover type at each point as log, brush, vegetation, boulder, overhang, or open (none). Log cover included submerged material $>10 \mathrm{~cm}$ in diameter; brush included material
$<10 \mathrm{~cm}$ in diameter. Submerged or flooded riparian vegetation, such as Alnus sp. and Cornus sp., were included as brush. Vegetation included aquatic vascular plants: often Ceratophyllum sp., Potamogeton sp., Sparganium sp., and Elodea sp. Overhang cover shaded fish from direct sunlight; we included undercut banks in this category.

To estimate the degree to which habitat characteristics were available in the study site, we took the habitat measures described above along 26 additional transects at $1.6 \mathrm{~km}$ intervals between Mio Dam and the backwaters of Alcona Pond. Using Strauss' linear index of electivity, we compared habitat use data pooled from the three transects within a fish's local range to pooled data from the 26 random transects. The index ranges from -1 to +1 with positive values indicating preference and negative values indicating avoidance. We also separated data from the random transects into two study areas: Mio to McKinley (17 transects) and McKinley to Alcona Pond (9 transects). We plotted frequency of occurrence for values of depth, mean column velocity, substrate, and cover to determine if habitat characteristics were evenly distributed throughout the study site or concentrated in either the upstream or downstream areas.

\section{Statistical analyses}

We generally used nonparametric analyses because samples were not normally distributed and did not have equal variances. We used Wilcoxon signed rank tests to compare mean summer and winter range size for three walleye tracked in both seasons. We used Mann-Whitney $U$ tests to make unpaired comparisons; for example, to compare mean summer range size for twelve walleye. We used Kolmogorov-Smirnov tests to compare frequency distributions. We calculated Pearson correlation coefficients to test correlations between habitat variables. We used paired $t$-tests to test if the electivity index values indicated significant habitat selection. We used SYSTAT software (Wilkinson 1989) to calculate Wilcoxon signed rank test, Kolmogorov-Smirnov tests, correlation coefficients, and $t$-tests. We used SPSS software (Norusis 1993) to conduct Mann-Whitney $U$ tests. Differences were considered statistically significant if $p<0.05$. 


\section{Results}

We successfully implanted 12 walleye (Table 1). Individual walleye movements were quite sporadic, with some fish remaining in the river, some in the reservoir, but most moving between these two areas (Figure 2). Eight of 11 walleye used both river and reservoir locations. In May 1996, we captured, implanted and released five walleye in the river. We located three of these fish in Alcona Pond during winter, and we tracked them when they returned to the river in April and May 1997. In April 1997, we implanted seven walleye from three different locations. The two walleye captured and released in Alcona Pond were not exuding gonad products at the time of surgery. The five walleye captured and released in the river were exuding gonad products at the time of surgery.
Summer range of walleye $(\mathrm{n}=14$, we tracked three individuals in both summer 1996 and 1997) varied from 0.1 to $40.7 \mathrm{~km}$ (median $=16.8 \mathrm{~km}$, Figure 2). There was no significant difference in mean summer range for five walleye tracked in summer $1996(4.6 \mathrm{~km})$ and nine walleye in summer $1997(15.7 \mathrm{~km})$. Winter range $(\mathrm{n}=3)$ varied from 23.3 to $46.6 \mathrm{~km}$ (median $=24.5 \mathrm{~km}$, Figure 2 ). Total range for three walleye tracked through both summer and winter varied from 40.0 to $46.7 \mathrm{~km}$. These distances are almost equal to the distance separating the dams that bound this reach.

Walleye established local ranges in both river and reservoir locations. Eight walleye used local ranges in the river during summer. When in the river, walleye frequently used habitats within the upstream area between Mio Dam and McKinley Bridge (Table 2). Seventy-one percent of walleye locations occurred in the first $25 \mathrm{~km}$ below Mio

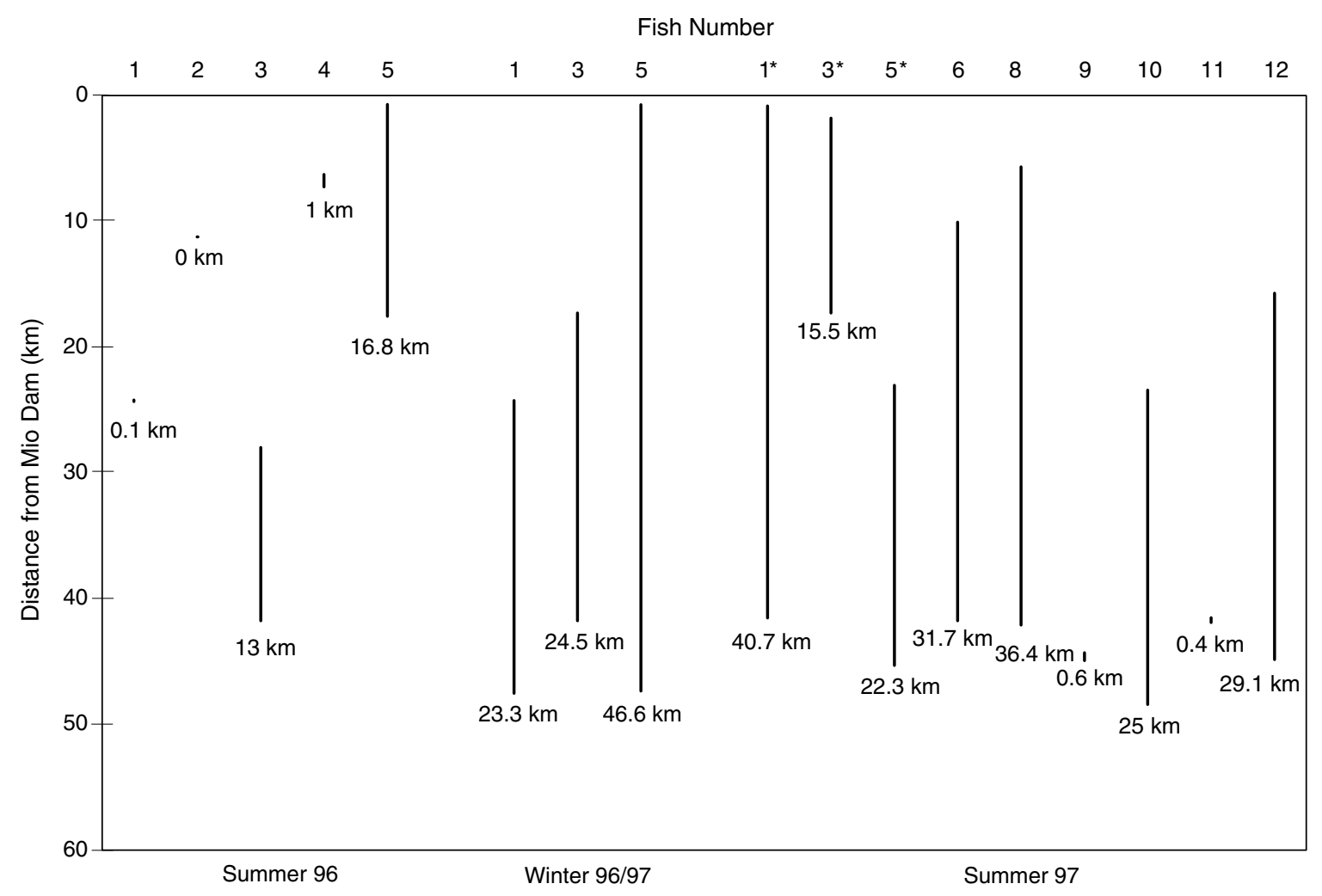

Figure 2. Seasonal range of movement by 11 walleye. Eleven fish were tracked in summer. Three fish tracked in both summer 1996 and 1997 are marked with an asterisk. Three fish were tracked in winter. High and low horizontal bars indicate upstream and downstream limits of fish movements. Numbers below horizontal bars indicate river distance, in kilometers, between upstream and downstream limits. 
Table 1. Summary of observed movement between river and reservoir.

\begin{tabular}{|c|c|c|c|c|c|c|}
\hline $\begin{array}{l}\text { Fish } \\
\text { Number }\end{array}$ & $\begin{array}{l}\text { Length } \\
(\mathrm{cm})\end{array}$ & $\begin{array}{l}\text { Date, location } \\
\text { of implant }\end{array}$ & $\begin{array}{l}\text { Observed movement } \\
\text { between river and } \\
\text { reservoir }\end{array}$ & $\begin{array}{l}\text { Date, location } \\
\text { of last contact }\end{array}$ & $\begin{array}{l}\text { Days } \\
\text { tracked }\end{array}$ & $\begin{array}{l}\text { Number of } \\
\text { observations }\end{array}$ \\
\hline W1 & 53 & 9 May 96, river & $\downarrow$ (Sept 96), $\uparrow$ (May 97) & 16 May 97 , river & 372 & 56 \\
\hline W2 & 54 & 9 May 96, river & None observed & 8 July 96 , river & 60 & 29 \\
\hline W3 & 50 & 9 May 96, river & $\downarrow$ (Oct 96), $\uparrow$ (April 97) & 9 June 97 , river & 396 & 42 \\
\hline W4 & 59 & 2 May 96, river & None observed & 6 September 96 , river & 127 & 28 \\
\hline W5 & 47 & 2 May 96, river & $\downarrow$ (Nov 96), $\uparrow$ (May 97) & 6 May 97, river & 362 & 26 \\
\hline W6 & 51 & 4 April 97, river & $\downarrow$ (May 97), $\uparrow$ (June 97) & 1 October 97 , river & 180 & 29 \\
\hline W7 & 49 & 4 April 97, river & None observed & 4 April 97 & 0 & 0 \\
\hline W8 & 46 & 4 April 97, river & $\downarrow$ (May 97), $\uparrow$ (June 97) & 1 October 97 , river & 180 & 39 \\
\hline W9 & 68 & 4 April 97, river & $\downarrow$ (May 97) & 2 October 97 , reservoir & 181 & 17 \\
\hline W10 & 64 & 3 April 97, reservoir & $\begin{array}{l}\uparrow(\text { May 97), } \downarrow \text { (July 97), } \\
\uparrow(\text { Oct 97) }\end{array}$ & 1 October 97, river & 181 & 31 \\
\hline W11 & 68 & 3 April 97, reservoir & None observed & 2 October 97 , reservoir & 182 & 17 \\
\hline W12 & 50 & 4 April 97, river & $\downarrow$ (May 97) & 31 July 97, reservoir & 118 & 17 \\
\hline
\end{tabular}

Up arrow indicates movement from reservoir to river site. Down arrow indicates movement from river site to reservoir. Month of movement in parentheses. Days tracked equal number of days between implant and last contact.

Table 2. Data are combined for eleven walleye tracked between May 1996 and August 1997. Distance downstream of Mio Dam indicates upper limits for inclusion in each category. Distances greater than $40 \mathrm{~km}$ represent reservoir locations.

\begin{tabular}{lc}
\hline $\begin{array}{l}\text { Distance downstream of } \\
\text { Mio Dam }(\mathrm{km})\end{array}$ & Percent of observations \\
\hline 5 & \\
10 & 10 \\
15 & 34 \\
20 & 15 \\
25 & 3 \\
30 & 9 \\
35 & 1 \\
40 & 0 \\
40 & 1 \\
\hline
\end{tabular}

Dam. Less than $2 \%$ of locations were between McKinley Bridge and Alcona Pond. Five different walleye used local ranges in the reservoir: three fish during summer and two fish during winter. Within the reservoir, locations were concentrated along the old river channel.

Walleye activity usually increased about $1 \frac{1}{2} \mathrm{~h}$ before sunset and continued through the night (Table 3). In the river, walleye patrolled short sections of shoreline (5-10 m) for 10-20 min at a time, then moved to another section of shoreline and began patrolling there. They continued this activity throughout the night. Usually they confined this activity to their local range, but individual walleye
Table 3. The percent of 5-minute observation periods that walleye were active at four times of day ( $\mathrm{N}=648$ observations). Data are combined for five fish and nine observation dates during summer 1996 and summer 1997.

\begin{tabular}{ll}
\hline Time of day & $\begin{array}{l}\text { Percent of periods that } \\
\text { fish were active }\end{array}$ \\
\hline Sunrise & 25 \\
Day & 18 \\
Sunset & 49 \\
Night & 81 \\
\hline
\end{tabular}

occasionally made nocturnal foraging movements of up to $2 \mathrm{~km}$. By sunrise, all walleye returned to their original resting site or had chosen another resting site within their local range.

We tracked one walleye while it traveled from its local range in the river to the reservoir. On 22 May 1997 at 21:00 h, we were monitoring the activity of $\mathrm{W} 8$ within its local range in the river. At 22:40 h it began swimming continuously downstream. We located it eight times during a $19.6 \mathrm{~km}$ journey downstream that lasted $5.25 \mathrm{~h}$. During this time, its average swimming speed was $1 \mathrm{~m} \mathrm{~s}^{-1}$, which was about the same as the water velocity. The fish was still swimming downstream at 04:00 h. We located it $10 \mathrm{~h}$ later, $11 \mathrm{~km}$ further downstream in the river. We located it 4 days later, in the reservoir.

In 1996 and 1997, walleye return to the reservoir after spawning was not synchronous; individual fish returned at different times between May and 
October. However, when a fish began to move to the reservoir, it did not gradually move downstream. On five occasions, we located individual walleye within their local ranges in the river and then next located them, generally $1-3$ days later, in the reservoir. These relatively sudden disappearances from the river suggest that other fish, besides W8, may have also made overnight journeys from the river to Alcona Pond.

Walleye local ranges frequently contained lowvelocity refuges and silt substrates (Table 4). Walleye did not select particular depths for their local ranges. They showed significant positive electivity for mean column velocities $<0.4 \mathrm{~m} \mathrm{~s}^{-1}$ and for silt substrate. Walleye seemed to select vegetation, brush, and logs and avoid open areas but the only significant electivity was for vegetation and brush. Local ranges occupied by three walleye in summer 1996 were occupied by different walleye in summer 1997. Data from the random transects indicated no significant differences in availability of particular depths, mean column velocities, substrate or cover types between the upstream and the downstream study areas.

\section{Discussion}

Walleye exhibited complex daily and seasonal movements that are likely attributed to spawning, overwintering, and foraging habitat requirements. Walleye habitat needs vary seasonally, and, in the river, habitat conditions vary from upstream to downstream and from year to year. In general, walleye spawned in the river, overwintered in the reservoir, and foraged either in the river or reservoir during summer. Although walleye moved long distances over the course of a year (up to $46.6 \mathrm{~km}$, nearly the maximum possible distance in this study site), they frequently occupied local ranges within the river and confined their foraging to small areas. Rivers generally have higher productivity per unit area than lakes and reservoirs, therefore fish need less area in a river to meet their metabolic needs, compared to a lake (Minns 1995). Differences in productivity between river and reservoir habitats could explain why several walleye selected river habitats during summer.

Walleye in the present study occupied sites in the first $25 \mathrm{~km}$ below Mio Dam and traveled through but did not occupy sites between McKinley Bridge and Alcona Pond. These results are consistent with Paragamian (1989), who observed $92 \%$ of adult walleye locations within $9.7 \mathrm{~km}$ of a dam on the Cedar River, Iowa, and noted that walleye would travel downstream through a degraded reach but did not stay in it. In summer 1997, three walleye made a second migration from the reservoir and

Table 4. Positive electivity index values indicate preference and negative values indicate avoidance. An asterisk indicates the index value was significantly different from zero $(p>0.05)$.

\begin{tabular}{|c|c|c|c|c|c|c|c|}
\hline Depth (m) & $\begin{array}{l}\text { Available } \\
(\mathrm{n}=284)\end{array}$ & $\begin{array}{l}\text { Used } \\
(n=160)\end{array}$ & Electivity & Cover type & $\begin{array}{l}\text { Available } \\
(\mathrm{n}=302)\end{array}$ & $\begin{array}{l}\text { Used } \\
(\mathrm{n}=176)\end{array}$ & Electivity \\
\hline$<0.4$ & 30.3 & 28.1 & -0.04 & Open & 69.9 & 51.7 & -0.15 \\
\hline $0.4-0.8$ & 31.3 & 30.0 & -0.02 & Overhang & 10.3 & 10.8 & 0.03 \\
\hline $0.8-1.2$ & 27.5 & 24.4 & -0.06 & Boulder & 2.0 & 1.7 & -0.08 \\
\hline $1.2-1.6$ & 7.4 & 12.5 & 0.26 & Vegetation & 4.0 & 8.0 & $0.33^{*}$ \\
\hline $1.6-2.0$ & 3.5 & 3.1 & -0.06 & Brush & 6.0 & 8.0 & $0.14^{*}$ \\
\hline \multirow[t]{2}{*}{$>2$} & 0 & 0 & NA & Logs & 6.6 & 16.5 & 0.43 \\
\hline & & & & Artificial & 1.3 & 3.4 & 0.44 \\
\hline $\begin{array}{l}\text { Mean column } \\
\text { locity }(\mathrm{m} / \mathrm{s})\end{array}$ & $\begin{array}{l}\text { ve-Available } \\
\qquad(\mathrm{n}=238)\end{array}$ & $\begin{array}{l}\text { Used } \\
(\mathrm{n}=128)\end{array}$ & Electivity & Substrate & $\begin{array}{l}\text { Available } \\
(\mathrm{n}=267)\end{array}$ & $\begin{array}{l}\text { Used } \\
(\mathrm{n}=128)\end{array}$ & Electivity \\
\hline 0 & 2.1 & 3.1 & 0.20 & Silt & 0.7 & 7.8 & $0.83^{*}$ \\
\hline$<0.4$ & 18.5 & 35.9 & $0.32 *$ & Sand & 21.0 & 32.0 & 0.21 \\
\hline $0.4-0.8$ & 39.9 & 29.7 & -0.15 & Gravel & 27.3 & 18.0 & -0.21 \\
\hline $0.8-1.2$ & 33.2 & 24.2 & -0.16 & Pebble & 38.2 & 35.2 & -0.04 \\
\hline $1.2-1.6$ & 6.3 & 7.0 & 0.05 & Cobble & 12.7 & 7.0 & -0.29 \\
\hline$>1.6$ & 0 & 0 & NA & Boulder & 0.0 & 0.0 & NA \\
\hline
\end{tabular}


established local ranges in the upstream area. These fish passed through $20 \mathrm{~km}$ of downstream sites without spending much time there. Despite general differences between the upstream and downstream areas described in the introduction and discussed in Zorn \& Sendek (2001), our habitat measurements did not show significant differences between depth, substrate, velocity, and cover type in the upstream and downstream areas. However, the upstream and downstream areas have different thermal characteristics. Zorn \& Sendek (2001) indicate that weekly water temperatures below dams in the Au Sable do not vary much around the mean temperature, but as downstream distance from the dam increases, variation around the mean also increases. Temperatures below Mio Dam vary only slightly around the mean during summer, but closer to the backwaters of Alcona Dam, the weekly maximum temperatures are higher and the weekly minimum temperatures are lower. This variation may make the downstream reach unsuitable for summer foraging, especially in cool summers.

All walleye tracked had access to both river and reservoir habitats, yet apparently spawned in the river. In May 1996, we captured five fish within $5 \mathrm{~km}$ of the Mio Dam tailwaters, presumably after they had spawned. In April 1997, all five fish we captured in the river were exuding gonad products at the time of surgery; two fish captured in Alcona Pond were not. Walleye migrated from the reservoir upstream to the Mio Dam tailwaters in as few as 3 or 4 days. Ager (1976) and Paragamian (1989) also observed long-distance spawning migrations in short periods of time. Dam tailwaters often serve as primary spawning sites for walleye (Crowe 1962, Ager 1976, Paragamian 1989, Jennings et al. 1996, McMahon \& Bennett 1996). Construction of impoundments degrades riverine environments but produces clean gravel-cobble substrate below the dam, thus creating suitable sites for walleye spawning (Paragamian 1989).

Jennings et al. (1996) presented evidence for a heritable component to walleye spawning site selection. Currently, Alcona Pond has a naturally reproducing walleye population, but walleye previously stocked in the pond were from a river spawning stock in the Muskegon River (Michigan Department of Natural Resources 2002). This could explain why walleye moved upriver to spawn rather than spawning in the reservoir. However, if Alcona Pond supports both river- and lake-spawning populations, we may have only sampled river spawners. Although we made several attempts, we only collected two fish from the reservoir. We collected the remaining ten fish in the upstream area during April and May. Thus, our sample may have been biased toward river spawners, if both river and lake spawners existed in the study site.

In the present study, walleye remained in the river for 4-24 weeks after spawning. Rawson (1957) and Paragamian (1989) noted similar protracted returns from spawning grounds. Water temperature could have an important influence on how long walleye remain in the river after spawning. Based on limited temperature data (USGS gauge, MDNR continuous-recording thermometers), the river was warmer in May and June 1996 than in 1997. In 1996, three of four walleye remained in the river throughout the summer. Walleye may have remained in the river because the river temperature warmed quickly after they spawned. In contrast, in 1997 all eight walleye returned to Alcona Pond by early June. In 1997, cold river temperatures may have forced them to return to the reservoir. Local anglers provided similar anecdotal evidence: they explained that walleye fishing in the river is good in warm summers and poor in cold summers. Movement between river and reservoir sites by three walleye during summer 1997 further suggests that walleye may use either river or reservoir habitats if river conditions are suitable.

Food availability could also contribute to the length of time that walleye remain in the river after spawning. Michigan DNR stocks small brown and rainbow trout (average length 15-19 cm) in the river each spring. Stocking trout at this time may result in a large proportion of newly stocked fish being eaten by post-spawning walleye with high forage demands. Two walleye established local ranges within $50 \mathrm{~m}$ of a stocking site in late May. We located other walleye near trout stocking sites during May and early June. In the Seminoe Reservoir, Wyoming, most of the 500000 fingerling trout stocked annually were eaten by walleye within a few weeks after planting (McMahon and Bennett 1996). In spring, post-spawning walleye have large energy demands and stocked trout are particularly vulnerable to predation by walleye (McMahon \& Bennett 1996). Post-spawning walleye returning to Alcona Pond may encounter high concentrations of stocked 
trout. Walleye may delay their return to the reservoir in order to exploit this forage.

Our results suggest that maximum potential for interaction between brown trout and walleye occurs within the first $25 \mathrm{~km}$ below Mio Dam during summer. Brown trout and walleye may compete for feeding and resting sites in this reach. Both species used low-velocity sites for daytime resting and increased their foraging activity between dawn and dusk (DePhilip 1997). Since both species are piscivorous as adults, both probably seek highly productive feeding sites with concentrations of forage fish. Predatory interactions may also be likely. The presence of walleye near trout stocking sites suggests that walleye may be eating juvenile brown trout. Diet analysis within the study site could confirm whether diet overlap occurs between these species and whether walleye feed on young brown trout.

\section{Acknowledgements}

The Michigan Department of Natural Resources provided funding for this study. We thank Richard Clark, Edward Rutherford, James Schneider, Jim Gapczinski, Al Sutton, and all staff at the Michigan Department of Natural Resources Institute for Fisheries Research for providing administrative support, equipment, and editorial comments. Jerry Casey, Kyle Krueger, Troy Zorn, and Andy Nuhfer of the Michigan Department of Natural Resources provided equipment and supporting data. Sarah Cholger, Steven Day, Dana Hanselman, Sarah Zorn, Kevin Wehrly, and Geoff Miller provided field assistance.

\section{References}

Ager, L.M. 1976. A biotelemetry study of the movements of the walleye in Central Hills Reservoir, Tennessee. Proc. Ann. Conf. Southeast Assoc. Fish Wildlife Agencies 30: 311-323. Crowe, W.R. 1962. Homing behavior in walleyes. Trans. Am. Fish. Soc. 91: 350-354.

DePhilip, M.M. 1997. Daily and seasonal movements of large brown trout and walleye in an impounded reach of the $\mathrm{Au}$ Sable River, Michigan. Masters Thesis. University of Michigan, Ann Arbor. 69 pp.
Diana, J.S., D.F. Clapp, E.M. Hay-Chmielewski, G. Schnicke, D. Siler, W. Ziegler \& R.D. Clark. 1990. Relative success of telemetry studies in Michigan. Am. Fish. Soc. Symp. 7: 346352.

Furgeson, R. G. \& A.J. Dersken. 1971. Migrations of adult and juvenile walleyes Stizostedion vitreum vitreum in southern Lake Huron, Lake St. Clair, Lake Erie, and connecting waters. J. Fish. Res. Board Can. 28: 11331142.

Haas, R.C., M.C. Fabrizio \& T.N. Todd. 1988. Identification, movement, growth, mortality, and exploitation of walleye stocks in Lake St. Clair and the western basin of Lake Erie. Michigan Department of Natural Resources, Fisheries Research Report 1954, Ann Arbor. 71 pp.

Holt, C.S., G.D.S. Grant, G.P. Oberstar, C.C. Oakes \& D.W. Bradt. 1977. Movement of walleye, Stizostedion vitreum, in Lake Bemidji, Minnesota as determined by radio-biotelemetry. Trans. Am. Fish. Soc. 106: 163-169.

Jennings, M.J., J.E. Claussen \& D.P. Philipp. 1996. Evidence for heritable preferences for spawning habitat between two walleye populations. Trans. Am. Fish. Soc. 125: $978-982$.

McMahon, T.E. \& D.H. Bennett. 1996. Walleye and northern pike: boost or bane to northwest fisheries? Fisheries 21: 6-13.

Mesing, C.L. \& A.M. Wicker. 1986. Home range, spawning migrations, and homing of radio-tagged Florida largemouth bass in two central Florida lakes. Trans. Am. Fish. Soc. 115: 286-295.

Minns, C.K. 1995. Allometry of home range size in lake and river fishes. Can. J. Fish. Aquat. Sci. 52: 1499-1508.

Norusis, M.J. 1993. SPSS for Windows: Base System User's Guide, Version 6.0. SPSS Inc., Chicago, Illinois. 825 pp.

Paragamian, V.L. 1989. Seasonal habitat use by walleye in a warmwater river system as determined by biotelemetry. N. Am. J. Fish. Manag. 9: 392-401.

Rawson, D.S. 1957. The life history and ecology of the yellow walleye, Stizostedion vitreum, in Lac La Ronge, Saskatchewan. Trans. Am. Fish. Soc. 86: 15-37.

Ross, M.J. \& C.F. Kleiner. 1982. Shielded-needle technique for surgically implanting radio-frequency transmitters in fish. Prog. Fish-Cult. 44: 41-43.

Schlosser, I.J. 1991. Stream fish ecology: A landscape perspective. BioScience 41: 704-712.

United States Department of Agriculture, Soil Conservation Service. 1991. Streambank erosion inventory, The main branch of the Au Sable River Mio Pond to Rollways Campground. Report 1006562.

Wilkinson, L. 1989. SYSTAT: The System for Statistics. SYSTAT, Inc., Evanston, Illinois.

Zorn, T.G. and S.P. Sendek. 2001. Au Sable River watershed assessment. Michigan Department of Natural Resources. Fisheries Special Report 26, Ann Arbor. 234 pp. 